\title{
Attachment to amorphous iron sulfide increases the activity of strictly anaerobic, gallic acid-degrading bacteria
}

\author{
Ulrich Szewzyk and Bernhard Schink * \\ Fakultät für Biologie, Universität Konstanz, Konstanz, F.R.G.
}

Key words: Pelobacter acidigallici; Anaerobic bacterium; Iron sulfide; Surface; Attachment

\section{SUMMARY}

The effect of FeS-coated surfaces on substrate degradation and attachment of strictly anaerobic, gallic acid-fermenting bacteria was examined. Both strains used for this study, Pelobacter acidigallici strain MaGal2 and a newly isolated strain, Pelobacter acidigallici strain EGal, showed an increased degradation rate in the presence of FeScoated surfaces. Surfaces not coated with FeS had no effect compared to the control without added surfaces. For strain EGal, the optimal amount of FeS-coated glass surface for stimulation of degradation was determined. Stimulation was also achieved by addition of dithionite. Control experiments proved that the stimulatory effect of FeS surfaces was not due to a decrease in redox potential or the supply of iron or sulfide.

Correspondence 10: U. Szewyk. Present address: Statens Bakteriologiska Laboratorium, Vattensektion S-105 21 Stockholm, Sweden.

* Present address: Universität Tübingen, Lehrstuhl Mikrobiologie I, Auf der Morgenstelle 28, D-7400 Tübingen, F.R.G.

\section{INTRODUCTION}

The consequences of the attachment of bacteria to various surfaces has been studied since the beginning of this century [1]. In most cases it was observed that attached cells were physiologically different compared to free-living cells. These physiological differences concerned both growth rate [2] and metabolic activity [3-7]. In other studies, a concentrating effect by surfaces on dissolved organic compounds was demonstrated [8]. These findings suggest that bacteria in an oligotrophic environment might find better living conditions at surfaces where nutrients accumulate. It was also observed that attached bacteria are better protected against disinfectants [9].

Most of these studies were carried out with aerobic bacteria, while anaerobic bacteria have rarely been studied for their response to surface attachment, although they live typically in environments rich in particulate matter. Anaerobic bacteria on surfaces were studied mostly for reasons of technical application, e.g. to immobilize biomass for anaerobic waste water treatment $[10,11]$. 
In only a few cases has the direct of an interaction between anaerobic bacteria and surfaces been studied, for instance for the substrate utilization of sulfate reducing bacteria as correlated to the amount of clay particles present [12]. Amorphous iron sulfide, the typical particulate surface material in many anaerobic environments, supports growth of methanogenic bacteria $[13,14]$.

In the present work, we studied the effect of FeS on strictly anaerobic, fermenting bacteria. Special attention was paid to the length of the lag-phase after inoculation of a culture, the degradation rate for the substrate gallic acid, and the attachment and growth of the bacteria on FeScoated surfaces.

\section{MATERIALS AND METHODS}

\subsection{Source of organisms}

Pelobacter acidigallici strain MaGal2 [15] has been cultured in liquid media since its isolation. A new strain of a gallic acid fermenting bacterium, Pelobacter acidigallici strain EGal was enriched on surfaces by use of a bait method [16] in a eutrophic forest pond near Scheer, Kreis Sigmaringen, F.R.G. The new strain was isolated and cultivated to select for surface-colonizing bacteria as described previously [16].

\subsection{Media}

The freshwater and saltwater media used for cultivation and isolation were the sulfide-prereduced mineral salt solutions described previously [15,17]. Trace element solution SL10 [18], selenite/tungstate solution [19], 6 vitamin solution, and vitamin $B_{12}$ solution [20] were added to the media after autoclaving. Sodium gallate $(\mathrm{pH}$ 6.9) was stored as a $200 \mathrm{mM}$ stock solution under $\mathrm{N}_{2}$ atmosphere and added to the medium as the sole energy and carbon source before inoculation.

The iron solution contained $2.0 \mathrm{~g} \mathrm{FeCl}_{2} \cdot 4 \mathrm{H}_{2} \mathrm{O}$ and $12.8 \mathrm{~g}$ NTA per liter distilled water. The $\mathrm{pH}$ was adjusted to 6.0 .

\subsection{Test surfaces}

Glass sinter spools (height $7 \mathrm{~mm}$, diameter 7 $\mathrm{mm}$, wall thickness $2 \mathrm{~mm}$, porosity $60 \%$, internal surface area $0.2 \mathrm{~m}^{2} \mathrm{~g}^{-1}$, Schott, Mainz, F.R.G.), were used either uncoated or coated with agar or FeS. For agar-coating, the spools were dipped into a hot, $0.5 \%$ agar solution and dried under air. The FeS-coating was done as described previously [16]. All spools, coated or not, were stored in anoxic basal medium under $\mathrm{N}_{2} / \mathrm{CO}_{2}(90 / 10 \%, \mathrm{v} / \mathrm{v})$ gas mixture.

\subsection{Growth tests in batch cultures}

To test the influence of surfaces on lag phase and degradation rate, various surfaces were added to $50 \mathrm{ml}$ of anaerobic medium in $100 \mathrm{ml}$ serum bottles under $\mathrm{N}_{2} / \mathrm{CO}_{2}(90 / 10 \%, v / v)$. Cultures were inoculated and samples were taken with a syringe through the rubber stopper. All experiments were carried out at least in duplicate.

\subsection{Continuous flow system}

Attachment studies were carried out in a glass tube (volume $47 \mathrm{ml}$ ) sealed with a butyl rubber stopper and continuously flushed with anoxic medium via isoversinic tubes ( $5 \mathrm{~mm}$ diameter) at a constant temperature of $28^{\circ} \mathrm{C}$. A set of glass spools, either uncoated or coated with agar or FeS, was inserted into the tube. To start the system, cells of strain MaGal2 were injected into the tube and kept there without medium flow for $2 \mathrm{~h}$ to allow the cells to grow. Medium flow was then started at a rate $(45 \mathrm{ml} / \mathrm{h})$ which allowed growth both in the liquid phase and on the spools. After 2 to 7 days, the spools were removed and prepared for scanning electron microscopic examinations.

\subsection{Scanning electron microscopy}

Spools were washed twice in $66.7 \mathrm{mM}$ phosphate buffer and fixed in cooled $\left(4^{\circ} \mathrm{C}\right)$ glutaraldehyde $(2 \%, \mathrm{v} / \mathrm{v}$, in phosphate buffer 66.7 $\mathrm{mM}, \mathrm{pH}$ 7.2). The fixed spools were dehydrated in a graded series of acetone and critical-point dried prior to mounting on aluminum stubs and sputter-coating with carbon, gold, and carbon. The spools were examined in a Philips model 505 scanning electron microscope operated at $10 \mathrm{kV}$.

\subsection{Chemical analysis}

Gallic acid was quantified by measuring the absorption at $212 \mathrm{~nm}$ with a Gilford 250 spectro- 
photometer. Sulfide was determined photometrically [21].

\section{RESULTS AND DISCUSSION}

The type strain of the gallic acid fermenting, strictly anaerobic bacterium Pelobacter acidigallici, strain MaGal2, was examined for a possible influence of various surfaces on its gallic acid degradating activity. Of the surfaces tested (FeSor agar-coated glass spools and uncoated glass spools) only FeS coatings caused a visible decrease of the lag phase. All other surfaces had no effect as compared to the control without any surfaces added (Fig. 1). Strain MaGal2 has been maintained in liquid culture with $10 \mathrm{mM}$ gallic acid since its isolation in 1981, and may have adapted to this type of growth ever since. It has been reported that bacteria change their surface characteristics under these conditions, e.g. by loss of a glycocalyx [22] and, therefore, change in attachment capability. Such a change might also have occurred in strain MaGal2, and therefore its reaction to $\mathrm{FeS}$ addition was only slight. To avoid changes in attachment behavior and physiology due to culture conditions, an enrichment and cultivation method was used which selected for

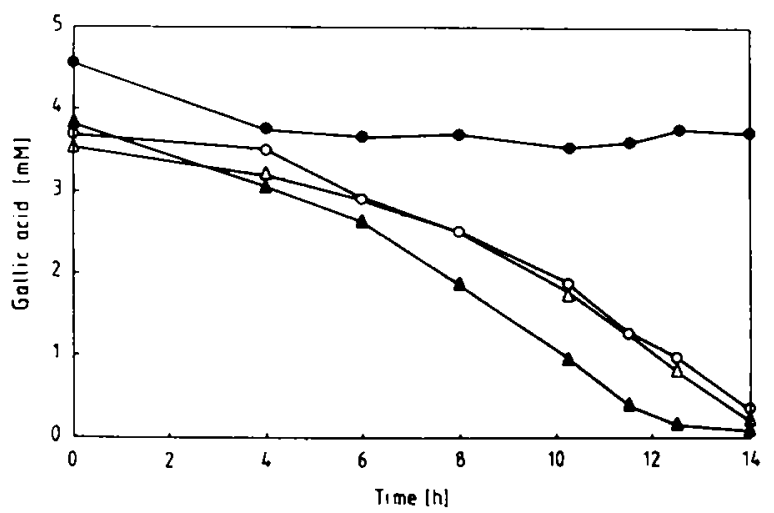

Fig. 1. Time course of gallic acid degradation by $P$. acidigallici strain $\mathrm{MaGal} 2$ in the presence of various surfaces. (๑) Control (FeS-coated spools without bacteria); $(\Delta)$ no surfaces added; (O) uncoated glass spools added; (A) FeS-coated spoois added.

surface-colonizing bacteria [4]. A new freshwater isolate of $P$. acidigallici, strain EGal, was obtained by this method and was used for all further experiments.

In contrast to strain MaGal2, the new isolate EGal was significantly more influenced by addition of FeS-coated surfaces. As shown in Fig. 2a, cells of strain EGal grew only after addition of at least one FeS-coated glass spool. In order to investigate if the enhancement of growth was correlated to the amount of FeS-coated spools, vari-
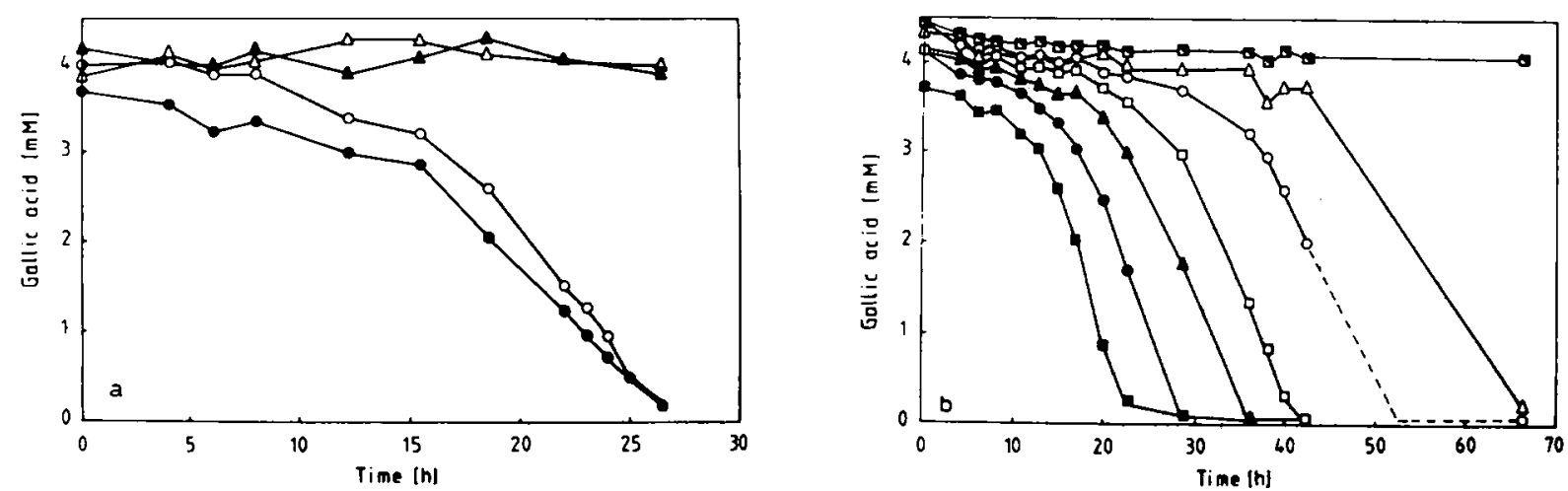

Fig. 2. Time course of gallic acid degradation by $P$. acidigallici strain EGal. (a) Dependence of lag-phase on addition of various surfaces: $(\Delta)$ control-no surfaces added; $(0)$ addition of $100 \mu \mathrm{M}$ dithionite; ( $\Delta$ ) addition of 40 glass spools; ( $\bullet$ ) addition of 40 FeS-coated glass spools. (b) Dependence of lag-phase on the number of FeS-coated glass spools: ( $\Delta$ ) control without addition of surfaces; ( $\triangle) 1,(0) 3,(\square) 5,(\Delta) 10,(\bullet) 20,(\square) 40$ FeS-coated glass spools added. 

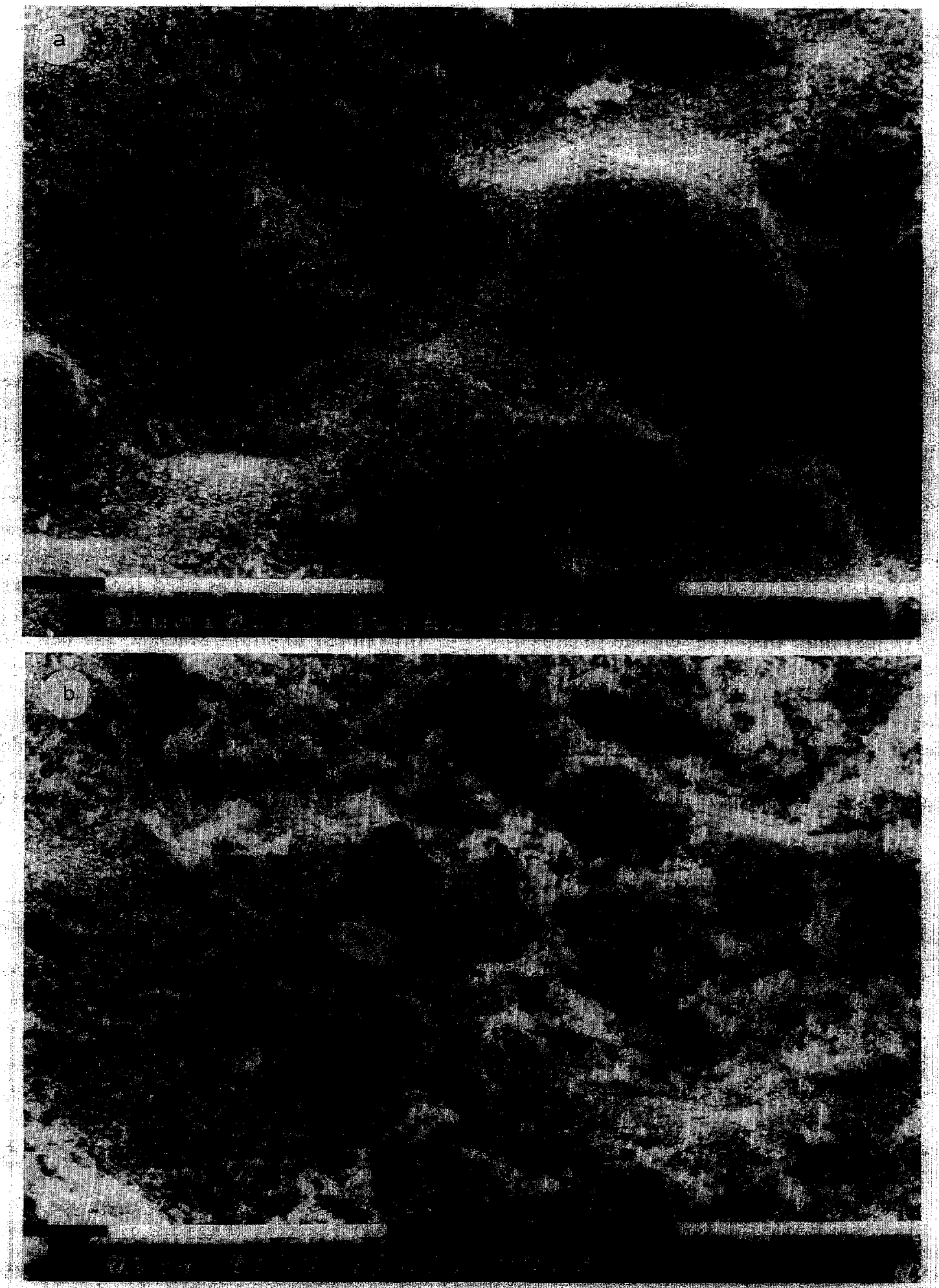

Fig. 3. Scanning electron microscope pictures of glass spools oolonized by P. acidigallici strain NatGal2 (a) Agar-coated glass spool; (b) FeS-coated glass spool. 
ous numbers of spools ( $0-120)$ were added in one series of experiments (Fig. 2b). The shortest lag phase was measured in the flasks with 40 FeScoated spools. More than 40 (up to 120) spools did not decrease the lag phase any further (data not shown).

For evaluation of the mechanisms behind the effect of FeS on the activity of fermenting bacteria, the influence of iron, sulfide, and of changes in redox potential were examined. Neither iron $(0.05$ $\mathrm{ml}$ iron solution per $50 \mathrm{ml}$ medium) nor additional sulfide caused increased degradation rates. These results indicate that the cells are not limited by iron or sulfide, but that the stimulatory effect is due to $\mathrm{FeS}$ as such.

The influence of a reduced redox potential was examined by addition of dithionite $(100 \mu \mathrm{M})$. Lag phases were shortened, as they were with the optimum number of FeS-coated spools (Fig. 2a). Addition of an optimum number of FeS-coated spools together with dithionite resulted in an even higher stimulation than by each alone.

Scanning electron microscopic examination of spools which were exposed in the continuous flow system revealed remarkable differences in colonization for the three different surfaces. The lowest colonization was found on the untreated glass spools, and most of the cells on the surface were single cells. On the agar-coated glass spools, colonization was significantly higher, but still mostly single cells and only few microcolonies were observed (Fig. 3a). By contrast, the spools coated with $\mathrm{FeS}$ were much more densely colonized, especially in the cracks (Fig. 3b). These observations indicate that both agar and FeS increase the attachment rate, but FeS stimulates growth on the surface in addition, as indicated by the formation of large colonies. From the data presented, we conclude that addition of particulate FeS stimulates growth of the gallic acid fermenting bacteria on or near the FeS particles. The mechanism(s) of this stimulation is unknown. Since gallic acid reacts easily with iron ions it may be bound and accumulated at the FeS surface. However, even $140 \mathrm{FeS}$-coated glass spools did not decrease the gallic acid concentration in the surrounding medium. Therefore, only very small amounts of gallic acid may be surface-bound and replaced after degradation, and iron sulfide may act as a catalyst as discussed recently [23]. On the other hand, iron sulfide might also act as an unspecific protectant, e.g. as a redox buffer. At the moment it is not possible to decide how iron sulfide supports $P$. acidigallici, but certainly it might be useful both for isolation of new organisms as well as for application of anaerobic bacteria in biotechnology.

\section{ACKNOWLEDGEMENTS}

The authors are greatly indebted to Professor Dr. N. Pfennig for support and valuable discussions. We would also like to thank Schott Co., Mainz, who made the glass sinter spools available to us. This work was supported by the Deutsche Forschungsgemeinschaft.

\section{REFERENCES}

[1] Söhngen, N.L. (1913) Zentralbl. Bacteriol. II. Abt. 38, 621-647.

[2] Conn, H.J. and Conn, J.E. (1940) J. Bact. 39, 99-100.

[3] ZoBell, C.E. (1937) J. Bact. 33, 86.

[4] ZoBell, C.E. (1943) J. Bact. 46, 39-56.

[5] Fletcher, M. (1979) Arch. Microbiol. 122, 271-274.

[6] Fletcher, M. (1986) Appl. Environ. Microbiol. 52, 672-676.

[7] Audic, J.M., Faup, G.M. and Navarro, J.M. (1984) Water Res. 18, 745-750.

[8] Södergren, A. (1982) Environ. Poll. Ser. A. 27, 263-274.

[9] LeChevallier, M.W., Hassenauer, T.S., Camper, A.K. and McFeters, G.A. (1984) Appl. Environ. Microbiol. 48, 918923.

[10] Switzenbaum, M.S. (1983) Enzyme Microb. Technol. S, 242-250.

[11] Szewzyk, U. and Schink, B. (1989) Appl. Microbiol. Biotechnol. 32, 346-349.

[12] Laanbroek, H.J. and Geerlings, H.J. (1983) Arch. Microbiol. 134, 161-163.

[13] Brock, T.D. and O'Dea, K. (1977) Appl. Environ. Microbiol. 33, 254-256.

[14] Oremland, R.S., Marsh, L. and Des Marais, D.J. (1982) Appl. Environ. Microbiol. 43, 462-468.

[15] Schink, B. and Pfennig, N. (1982) Arch. Microbiol. 133 , 195-201.

[16] Szewzyk, U. and Pfennig, N. (1986) J. Microbiol. Methods $5,289-294$. 
[17] Widdel, F. and Pfennig, N. (1981) Arch. Microbiol. 129, $395-400$.

[18] Widdel, F., Kohring, G.W. and Mayer, F. (1983) Arch. Microbiol. 134, 286-294.

[19] Tschech, A. and Pfennig, N. (1984) Arch. Microbiol. 137. 163-167.
[20] Pfennig, N. (1978) Int. J. Syst. Bacteriol. 28, 283-288.

[21] Cline, D. (1969) Limnol. Oceanogr. 14, 454-458.

[22] Costerton, J.W. and Irvin, R.T. (1981) Ann. Rev. Microbiol. 35, 299-324.

[23] Williams, R.J.P. (1990) Nature (Lond.) 343, 213-214. 